三重県宮川村の春日谷における2004年台風21号時に発生した斜面災害の地質素因(予察報告) Geological factor of slope failures caused by the $21^{\text {st }}$ typhoon, 2004, within the Kasugadani Valley of the Miyagawa-mura, Mie Prefecture, Southwest Japan (Preliminary report)

株式会社 環境地質（現：富山大学）／柏木健司 Kankyo Chishitsu Co., Ltd. (Toyama University) / Kenji KASHIWAGI

キーワード : Miyagawa, Kasugadani Valley, slope failure, accretionary complex, dismembered formation Key words : 宮川, 春日谷, 斜面崩壊, 付加体, 分断相

1.はじめに

2004年 9 月29日，日本列島を縦断した台風21号は，紀 伊半島東部に位置する三重県宮川村に多大な災害の痕跡 を残した。とくに，宮川支流の春日谷で生じた大規模な 斜面崩壊は，春日谷流域に大量の崩壊堆積物を供給し， その結果として谷流域に天然ダムを形成した。現在, 宮 川村の災害の速報がいくつか公表されている（近藤ほか, 2004 ; 林ほか, 2005)。しかし, 災害発生場の崩壊斜面と 地質との関係については十分に把握されていない。この 原因の一つとして，付加体地質の観点に基づく宮川村周 辺の大縮尺の地質図の整備・公表が遅れていることが挙 げられる。このような現状において, 災害地質の解析に 必須の大縮尺の地質図の早期公表が急務と考えられる。
本稿の目的は，筆者が2002〜2003年度に行った 5 万分の 1 地質図幅「長島」の調査研究で作成した春日谷流域の 地質図と地質記載の詳細を公表し，斜面崩壊の発生原因 を地質素因の側面から議論することにある。

\section{2. 春日谷流域の秩父北帯の地質}

宮川村を東北東方向に流下する宮川の南西側山地斜面 の基盤岩は，三波川帯の結晶片岩とその南側の秩父北帯 の地層から構成される。このうち, 秩父北帯の非変成 $(一$ 部, 弱変成) 付加体堆積岩類は, 岩相組み合わせと堆積 年代の相違に基づいて，断層で境される四つのコンプ レックス（Ｉａ，I b，I c，I d)に区分される(柏木, 2002 ; 柏木ほか, 2005) (図 - 1 )。春日谷水系の秩父北帯は，北

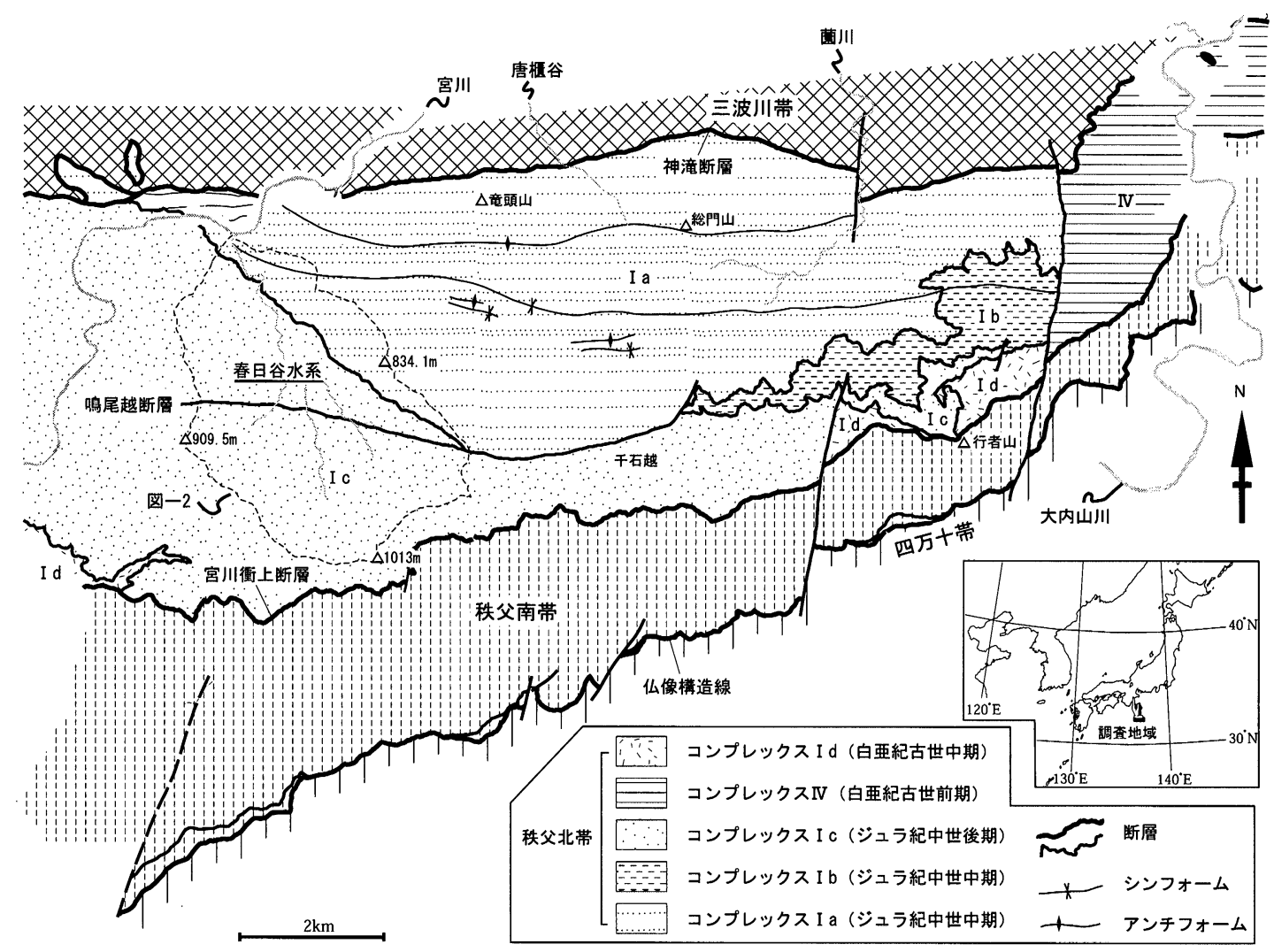

図-1 宮川村の秩父北帯の地質概略図

Fig. 1 Geological outline of the Northern Chichibu Belt in the Miyagawa-mura 
東側のコンプレックス I a と南西側の広い範囲を占める コンプレックス Icで構成される。コンプレックス I aは, 断層を介してコンプレックス I c の構造的上位に累重す る(図 - 2 )。

コンプレックス I aは, 複数の岩型のブロックを泥岩 基質中に含む混在岩から構成され，地層全体としてメラ ンジュの特徴を持つ。基質の泥岩は, $1 \mathrm{~mm}$ 以下の間隔 で密に発達する剪断面の発達で特徴づけられる。含まれ るブロックは, 緑色岩, 石灰岩, チャート, 珪質泥岩, 砂岩，砂岩泥岩細互層などで，とくに緑色岩と砂岩が卓 越する傾向にある。緑色岩は玄武岩質溶岩を多く含む。
一般に，ブロックは基質に発達する剪断面に沿って伸長 し，しばしば非対称変形構造の形態を示す。

コンプレックス I cは，東西走向で急傾斜する鳴尾越 断層（仮称）を境に，岩相組み合わせの異なる北側と南 側の区域に細分される。北側のコンプレックス I cは, チャートと陸源砕屑岩の構造的繰り返しで特徵づけられ る。チャートは頻繁に層状酸性凝灰岩を伴い，しばしば 急崖を形成する。陸源砕屑岩は塊状粗粒砂岩から主に構 成され，少量の砂岩優勢または泥岩優勢の砂岩泥岩互層 とその破断相（broken formation）ないし分断相（dismembered formation) (Raymond, 1984 ; 中江, 2000) を

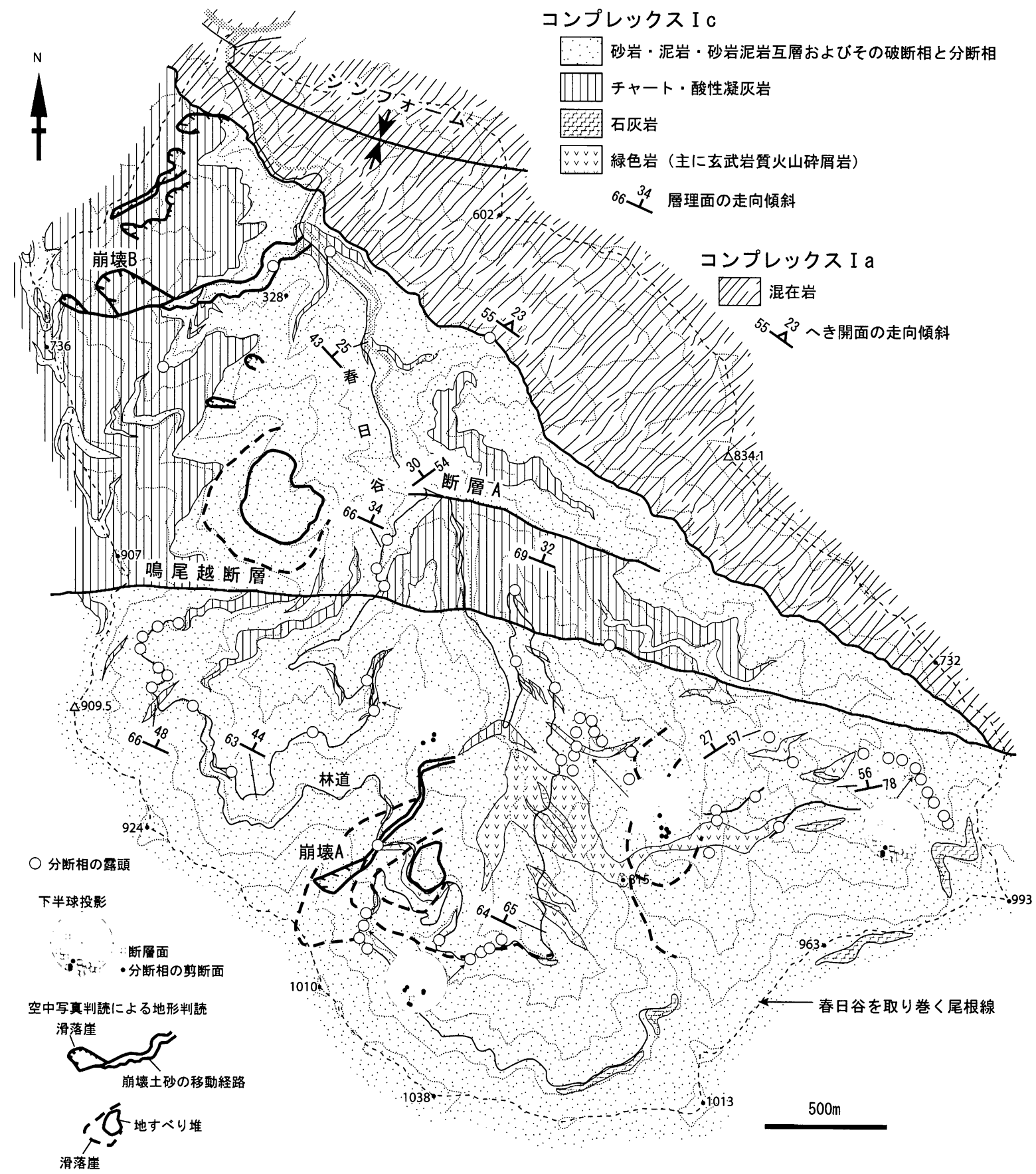

図一２春日谷流域における秩父北帯の地質図

Fig. 2 Geological map of the Northern Chichibu belt in the Kasugadani Valley 
伴う。なお，破断相と分断相は，それぞれ砂岩泥岩互層 が構造変形を受けた産状を指す。破断相は，露頭におい て側方への砂岩の断続的な連続性に基づき，砂岩と泥岩 の互層状態への復元が可能な産状を指す。一方，破断相 に比較してより強い変形を受けた分断相は，泥岩中に砂 岩をブロック状ないし層状に孤立して含み，砂岩と泥岩 との層序関係の復元が困難な産状を示す（写真 - 1)。 また, 分断相中の泥岩は, 一般に幅数 $\mathrm{mm}$ 数 $\mathrm{cm}$ 間隔 で発達する剪断面を有し，前断面で囲まれる混岩岩片中 には葉理や砂岩薄層がしばしば認められる。分断相と破 断相は，しばしば一つの露頭内で共存し，漸移的な岩相 変化を示す。

鳴尾越断層南側のコンプレックスIcは, 緑色岩, 石 灰岩, チャート, 陸源砕屑岩の構造的繰り返しで特佺づ けられる。玄武岩質火山砕屑岩から主に構成される緑色 岩は，石灰岩をしばしば密接に伴って露出する。珪質粘 土岩と珪質泥岩がまれにチャートに伴われて産出する。 陸源砕首岩は, 塊状粗粒砂岩, 泥岩, 砂岩泥岩互層とそ の破断相ないし分断相から主に構成され，石灰岩砂を含 む含碟泥岩を少量伴う。また，緑色岩やチャート，砂岩 などを, 剪断面の発達する泥岩中にブロックとして含む 混在岩が, コンプレックス $\mathrm{I} a$ との境界断層の直下数 $\mathrm{m}$

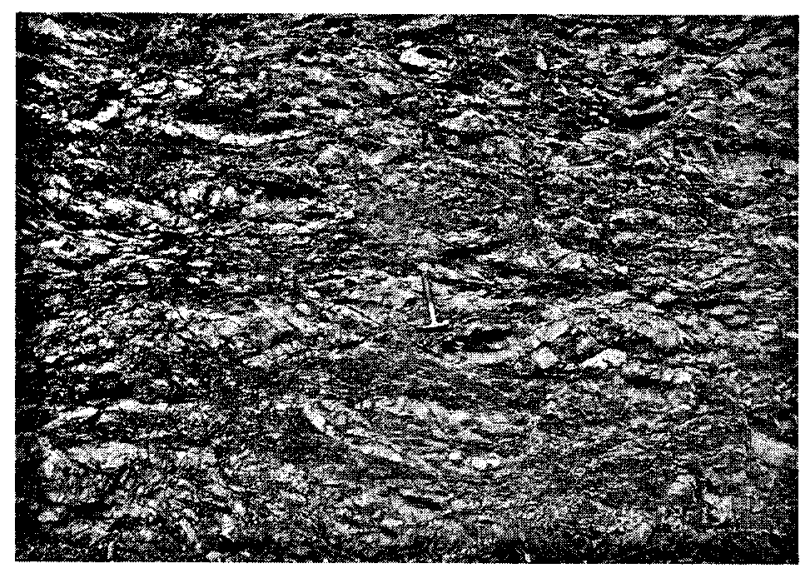

写真一 1 砂岩泥岩互層の分断相の産状（千石越付近） Photo 1 Field occurrence of dismembered formation of alternation beds of sandstone and mudstone
の構造層準を含む数力所に認められる。

鳴尾越断層は, 岩相分布の不連続性から推定される, 西北西－東南東走向の高角断層である。コンプレックス $\mathrm{I}$ aと I cの境界断層を切ることから，秩父北帯の構造累 重関係が完成した後に活動した断層の一つに位置づけら れる。また，その北方約 $500 \mathrm{~m}$ 付近の断層 $\mathrm{A} は$, 鳴尾越 断層に関連して形成されたと考えられる。鳴尾越断層の 南側には，砂岩泥岩互層の分断相が多くの露頭で観察さ れる(図-2)。同様の傾向は，鳴尾越断層と断層 $\mathrm{A} に$ 挟まれる範囲にも認められる。これら分断相の走向傾斜 は，一般に北西－東西－北東走向で北に中〜高角度の傾 斜を示す。また，分断相にほぼ平行な走向傾斜を有する 断層が，鳴尾越断層周辺において主に分断相に伴われて 多数発達する。鳴尾越断層とその近傍の分断相の分布す る帯状の範囲は，付加体の構造を切る白覀紀古世中期以 降に形成された変形帯に位置づけられる。

\section{3. 崩壊斜面周辺の地形と地質}

春日谷流域における大規模な斜面崩壊は，その上流の 北東向き斜面内に位置する崩壊 $\mathrm{A}$ ，春日谷下流に流れ込 む支流源頭部周辺にみられる崩壊Bで発生した（网一 2 ， 写真 -2$)$ 。崩壊Aは春日谷下流に多量の土砂を供給し, 崩壊Bはそれら堆積物をせき止める堤防状の高まりを形 成した。

崩壊Aの斜面（図－3）は，その南東側に広がる山地 斜面とともに, 周用よりも小さい谷の発達密度と, 滑ら かな斜面表層の形状を示す。この部分は，北東に開いた 最大幅および延長約750〜 1000mに至る不明瞭な旧地す ベり地形を呈する。さらに，崩壊Aの南東側に隣接する 斜面は，明暸な滑落崖と地すべり堆の地形的特徴を示す。 崩壊Aを含む周辺の地質は，林道沿いの調查に基づくと， 塊状粗粒砂岩, 砂岩泥岩互層とその分断相, 泥岩, 含碟 泥岩などの陸源砕屑岩から主に構成され，少量のチャー 卜と石灰岩，玄武岩質火山砕屑岩を含むと判断される。 砂岩泥岩互層の分断相が所々に露出し, 鳴尾越断層に関 連する変形帯に含まれている。

崩壊Bの発生した支流の沢は, 標高700m付近の尾根

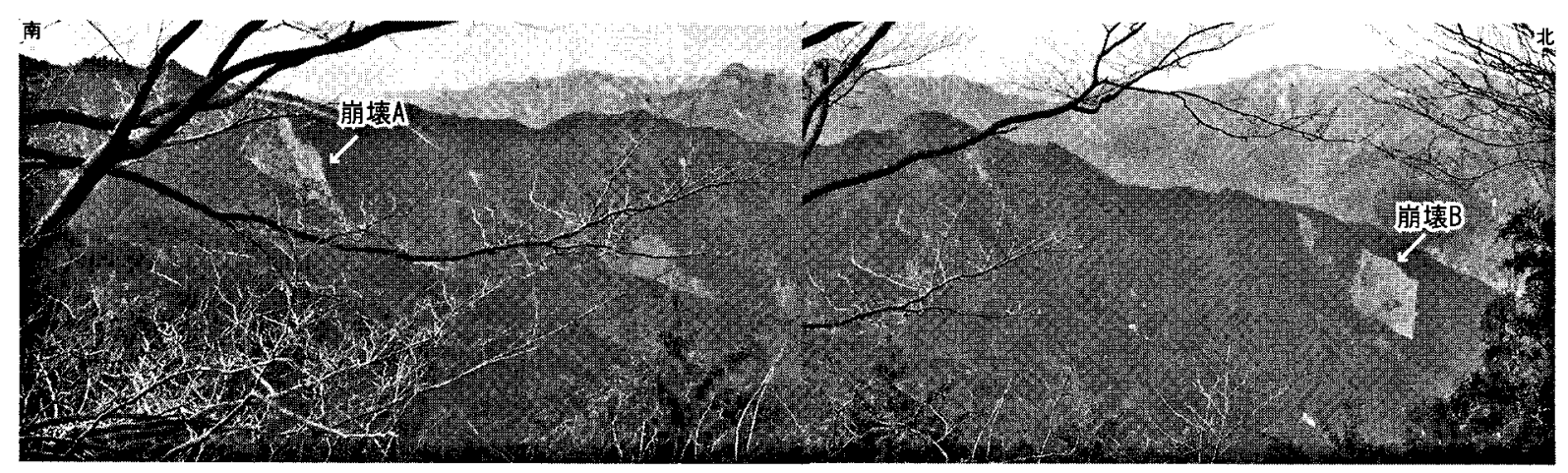

写真一 2 崩壊Aと崩壊Bの遠望

Photo 2 Panoramic view of the slope failures A and B 


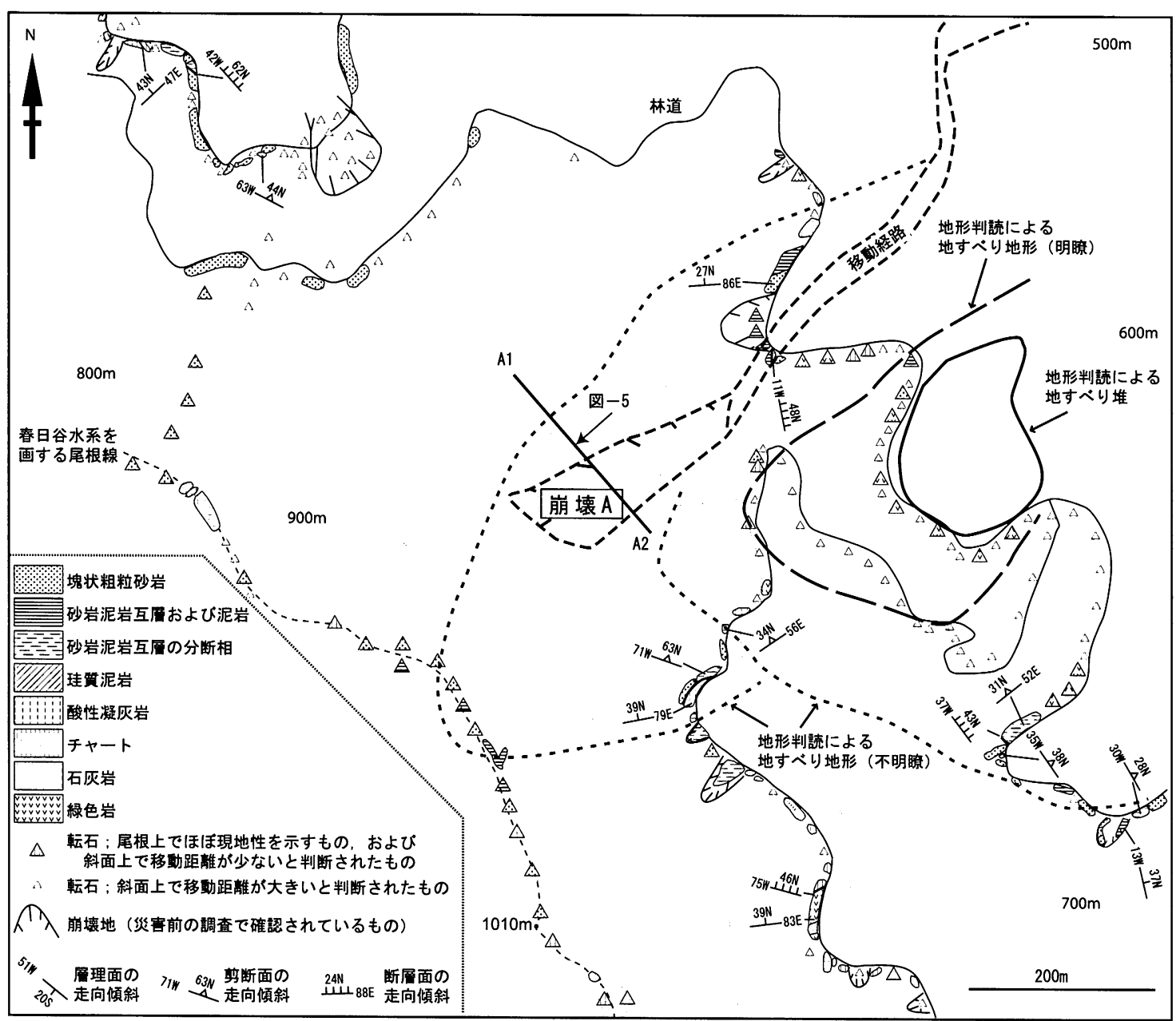

図一 3 春日谷上流の崩壊A周辺におけるコンプレックス I cのルートマップ

Fig. 3 Route map of the Complex I $c$ around the slope failure A

から春日谷本流の標高 $180 \mathrm{~m}$ 付近まで，東から東北東方 向に緩く蛇行しながら伸びている。標高 $350 \mathrm{~m}$ 付近の遷 緩点を境に，沢の河床勾配は上流で約 $35 \sim 20^{\circ}$ ，下流側 で $10^{\circ}$ 前後である（図-49b-d区間）。炎害発生前に 作成した沢の下流部を含む隣接する沢のルートマップ （図-4のa-c-d区間）によると，岩相構成は上流側 の層状酸性凝灰岩とチャートを主体とする部分（以下， 酸性凝灰岩卓越相）と，下流側の塊状粗粒砂岩を主体と する部分（以下，砂岩卓越相）に明暸に区分される。両 者は断層で接するとともに，層厚数 $\mathrm{m}$ 以上の分断相が断 層直下の砂岩卓越相中に観察される。崩壊Bは，遷緩点 より上流側の沢左岸の斜面に発生しており，砂岩卓越相 直上の酸性凝灰岩卓越相から構成されている。なお，隣 接する沢（図－3のa-c区間）において，酸性凝灰岩の 急崖は下位の分断相に対してオーバーハングしている。

\section{4. 考察}

斜面崩壊の発生機構を明らかにする上で，崩壊発生斜 面の地質状況を正確に把握することが重要である。以下 では，災害発生前に実施した野外調查の結果を基に，崩 壞発生斜面の地質状況を復元し，その崩壊機構について
考察を行う。

春日谷の二つの斜面崩壊は，いずれもコンプレックス I cの分布域で生じている。崩壊Aの斜面は，林道と尾 根沿いの岩相分布に基づくと, 泥岩を挟む塊状砂岩, お よび緑色岩とチャートを伴う石灰岩から主に構成される。 また，巨視的には鳴尾越断層の変形帯の範囲に含まれる ことから，砂岩泥岩互層の分断相が所々に挟在されてい ると考えられる（図一 5 のA）。さらに，崩壊斜面は地 形的に，旧地すべり地形の源頭部に位置する旧滑落崖に 当たる。以上の地質および地形デー夕に基づくと，崩壊 発生前の斜面は，その表層において多数の不連続面に沿 う開口割れ目を伴う緩み領域を断続的に形成していたと 考えられる。集中的な降雨に伴い，緩み領域の開口割れ 目に沿う流動化が進行し，最終的に大規模な表層崩壊に 至ったと解釈される。

一方，春日谷下流に堤防状の高まりを形成した崩壊B は，酸性凝灰岩とチャートから主に構成される酸性凝灰 岩卓越相を主体に，最下部に分断相を伴う斜面で発生し たと推定される（図-5のB）。隣接する沢では，分断 相の直上で酸性凝灰岩の急崖がオーバーハングしている 産状が観察された。また, 酸性凝灰岩卓越相は斜面の所々 


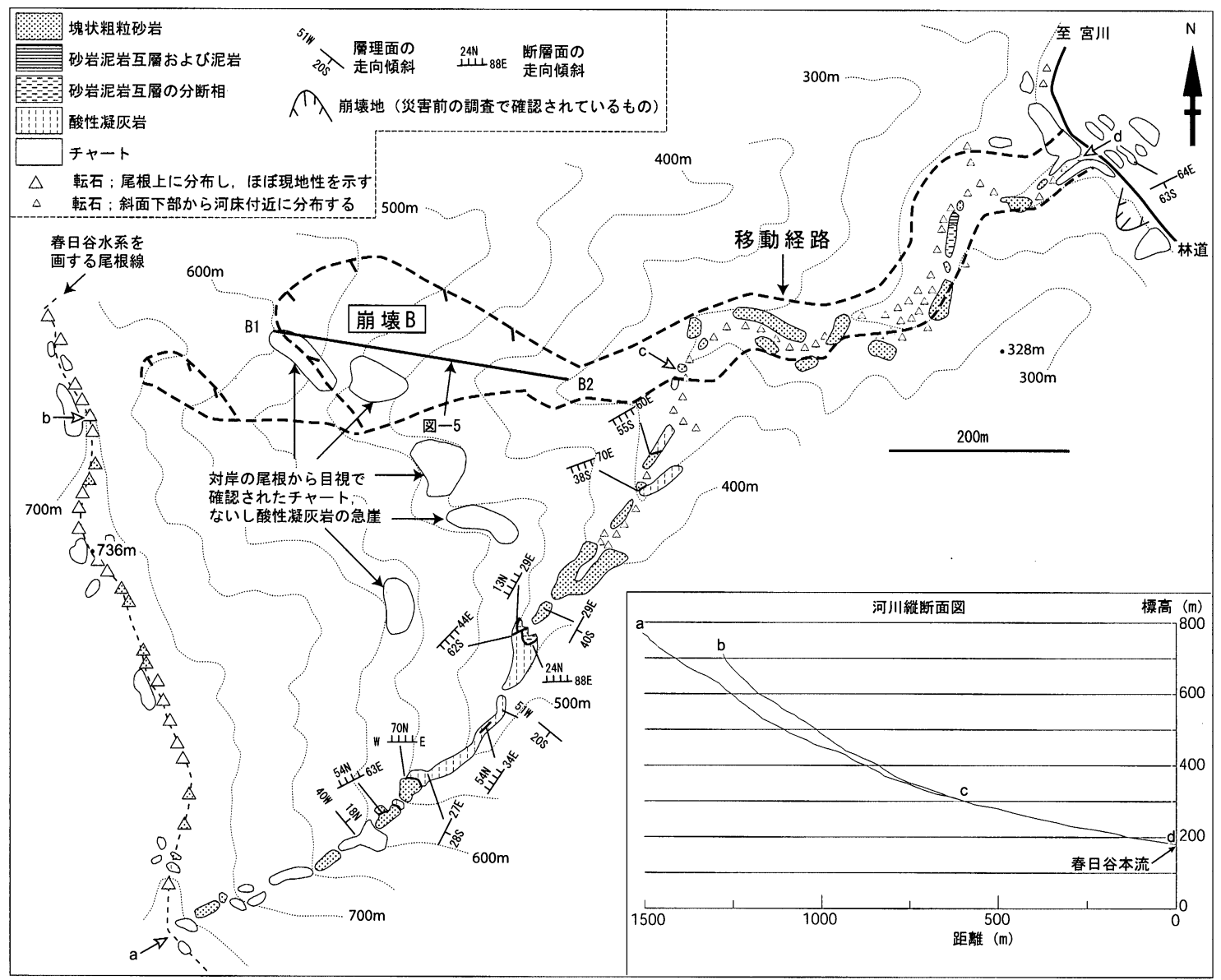

図ー4 春日谷支流の崩壊B周辺におけるコンプレックス I cのルートマップ

Fig. 4 Route map of the Complex I $c$ around the slope failure B

で急崖を形成し，遷緩線を境に下位の砂岩卓越相の構造 的上位に累重している。以上に基づくと，周囲に対して 凸斜面を形成していた酸性凝灰岩卓越相からなる斜面が, 背面に亀裂の形成を伴いながら不安定化し，崩壊に至っ た可能性が指摘される。

崩壊AとBに共通する地質素因の一つとして，砂岩泥 岩互層の分断相の存在が挙げられる。崩壊Aの発生要因 は，砂岩泥岩互層の分断相に直接に求められる。一方， 崩壊Bは主として酸性凝灰岩とチャートの斜面で発生し ている。ただし，その下盤側に断層を介して分断相が存 在するように，分断相の存在が間接的に斜面崩壊の発生 に関与していると考えられる。

\section{5. まとめと今後の課題}

本稿では，斜面崩壞の発生過程を考察するに際して， 災害前に得られた地質情報と，災害後の空中写真判読に よる地形情報を用いた。その結果として，春日谷におけ る斜面崩壊の直接的ないし間接的な地質素因の一つとし て, 剪断面の発達で特徵づけられる “砂岩泥岩互層の分 断相”の存在を指摘した。

今回の報告に際して, 以下の問題点が挙げられる。こ こで展開した斜面崩壊の発生機構に関する仮説は，災害 が発生した斜面の詳細な実地調査により検証される必要
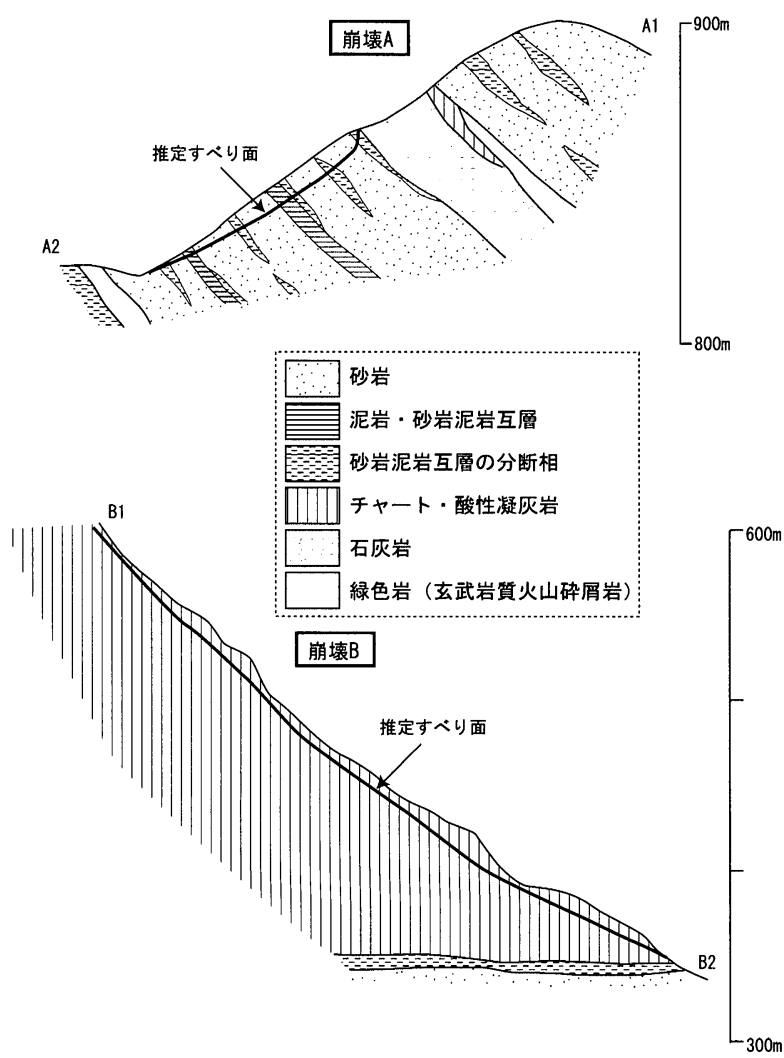

図ー 5 崩壊Aと崩壊Bの復元される地質状況

Fig. 5 Reconstructed geological occurrences of the slope failures $A$ and $B$ 
がある。また，これら二つの崩壊地周辺の同様の岩相か らなる斜面に，同程度の規模の斜面崩壊は発生していな い。斜面崩壊の発生場が, どのような地質と地形条件に 規制されているかを, 災害地質の視点で再度見直す必要 がある。また，その結果を基にしたハザードマップの作 成が，地域防災の観点から最終的に強く求められる。現 在, 筆者と共同研究者は崩壊斜面とその周辺の災害地質 調查を行い，今回の仮説の検証を進めている。稿を改め て，その詳細を報告する予定である。

\section{謝 辞}

春日谷の災害地質の調査に際して, 名古屋大学の常盤 哲也氏に御協力頂いている。産業技術総合研究所の中澤 努博士には，地形地質の観点から斜面崩壊の発生機構に 関して議論して頂いた。本誌の查読者には，多くの建設 的な改善点を指摘して頂いた。以上の方々に心から感謝 します。

\section{引用文献}

林 拙郎 - 土屋 智 - 近藤観慈 - 芝野博文 - 沼本晋也 - 小杉㹂一 朗・山越隆雄・池田暁彦（2005）：2004年 9 月29日，台風21号 に伴って発生した三重県宮川村の土砂災害（速報)，砂防学会 誌, Vol.57, No. 4, pp. 48-55.

柏木健司 (2002)：紀伊半島東部秩父带のジュラ紀中世〜白亜紀古 世前期付加複合体の 2 带配列. 日本地質学会酉日本支部会報, No. 120 , pp. 1 .

柏木健司・丹羽正和・常盤哲也（2005）：紀伊半島中央部の三之公 地域の秩父累带から産したジュラ紀古世放散虫化石。地啠学 雑誌, Vol.111, No. 3. pp. 170-181.

近藤観慈・沼本晋也・林 拙郎 (2004）：2004（平成16）年台風21 号による三重県宮川村の斜面災害. 日本地すべり学会誌, Vo. 41, No. 4, pp. $97-100$.

中江 訓 (2000)：付加複合体の区分法と付加体地質学における構 造層序概念の有効性. 地質学論集, No. 55, pp. 1-15.

Raymond, L. A. (1984) : Classification of mélanges. (Raymond, L. A., ed.), Melanges: Their Nature, Origin and Significance. Geol. Soc. America, Special Paper, No.198, pp.7-20.

（原稿受付 2005 年 3 月 29 日，原稿受理2005年 8 月 9 日） 